\author{
Mariola Szewczyk-Jarocka \\ The Mazovian State University in Plock \\ e-mail: m.szewczyk-jarocka@mazowiecka.edu.pl \\ ORCID: 0000-0001-9048-9513
}

\title{
OPINIONS OF SOCIALLY EXCLUDED INDIVIDUALS ON CONDUCTING BUSINESS ACTIVITY AND BEING EMPLOYED ON A FULL-TIME BASIS IN VIEW OF OWN RESEARCH
}

\section{OPINIE OSÓB WYKLUCZONYCH SPOLECZNIE NA TEMAT DZIALALNOŚCI GOSPODARCZEJ IPRACY NAETACIEWŚWIETLE BADAŃ WLASNYCH}

DOI: $10.15611 /$ pn.2019.5.08

JEL Classification: J66

Summary: The main objective of the considerations presented in the article is the attempt to verify the opinion of excluded individuals on conducting a business activity and being employed on a full-time basis. Detailed objectives concerning the analysis of the opinions of those surveyed were also adopted together with an assessment of the types of economic activity that the participants of the survey would like to conduct. The results of the questionnaires obtained from 350 respondents. As a result of the analyses, the author concluded that women as well as respondents with a secondary education more often express the will to take up a fulltime job. Statistically significant differences were recorded when it comes to the assessment of hairdressing and beauty care services between the persons with university education and those with secondary education as well as those without it. Statistically significant differences were also recorded in the context of taxi services between the persons without a secondary education and the persons with a university and secondary education. What is more, statistically significant differences were recorded in the assessment of childcare or caring for the elderly as well as the assessment of construction services.

Keywords: social exclusion, own research, full time employment, economic activity.

Streszczenie: Głównym celem rozważań zaprezentowanych w artykule była próba zweryfikowania opinii osób wykluczonych na temat działalności gospodarczej i pracy na etacie. Przyjęte zostały także cele szczegółowe dotyczące analizy opinii badanych na temat pracy na etacie oraz ocena rodzajów działalności gospodarczej, którą chciałyby prowadzić osoby badane. Do analizy włączono wyniki badań ankietowych otrzymane od 350 respondentów. W efekcie analiz autorka doszła do wniosku, że kobiety i osoby z wykształceniem średnim częściej wyrażają chęć podjęcia pracy na etacie. Stwierdzono istotne statystycznie różnice 
w zakresie ocen usług fryzjersko-kosmetycznych, które zachodziły pomiędzy osobami z wykształceniem wyższym a osobami z wykształceniem średnim i osobami bez wykształcenia średniego. Stwierdzono także istotne statystycznie różnice w zakresie ocen usług taksówkarskich, które zachodziły pomiędzy osobami bez wykształcenia średniego a osobami z wykształceniem wyższym i osobami z wykształceniem średnim. Ponadto stwierdzono istotne statystycznie różnice zachodzące w zakresie ocen opieki nad dzieckiem lub osobą starszą i w zakresie ocen usług budowlanych.

Słowa kluczowe: wykluczenie społeczne, badania własne, praca na etacie, działalność gospodarcza.

\section{Introduction}

The process of preventing social exclusion is called social inclusion. It makes it possible for individuals suffering from exclusion to become part of society, as well as enter the market of registered work. The necessary condition here consists in increased social awareness, the active approach and motivation of the unemployed. The following reasons are the most important in the context of the subject matter of the research:

- willingness to verify the common opinion that appropriate activities assist the unemployed in entering the market of registered work or conducting a business activity,

- lack of comprehensive research concerning the analysis of opinions on full-time employment and conducting a business activity.

Taking the above into consideration, the main objective of analyses presented in the article consists in the attempt to verify the opinion of those suffering from social exclusion on conducting a business activity and being employed on a full-time basis. The research task consists in the analysis of the abovementioned opinions concerning the given topics.

The main purpose of the empirical study designed and conducted by the author was to collect information concerning social inclusion.

The information concerning individuals suffering from social exclusion on being employed on a full-time basis and conducting business activity was collected in particular by means of the empirical study designed and conducted by the author.

The following detailed objectives were adopted for this general research framework:

1. Analysis of the opinion of those surveyed concerning the fact of being employed on a full-time basis.

2. Assessment of the types of economic activity that those surveyed would like to conduct.

The conclusion drawn from the empirical study, supported with the information used in the article and obtained from secondary sources, made it possible to verify the following hypotheses: 
H1: Women and respondents with a secondary education more often express the readiness to take up a full-time job.

H2: Statistically significant differences were recorded when it comes to the assessment of hairdressing and beauty care services between those with a university education and those with a secondary education, as well as those without it.

H3: Statistically significant differences were recorded in the context of taxi services between persons without a secondary education and those with a university and secondary education.

H4: Statistically significant differences were recorded in the assessment of childcare or caring for the elderly, as well as the assessment of construction services.

The questions to which the answers were searched for while realizing the research project were:

- Who expresses willingness to take up a full-time job?

- What are the assessments of the types of business activity that the unemployed would like to conduct?

Subject-related literature together with own empirical research were used in order to realize the research task formulated in this way. Statistical tests and descriptive methods were applied. The results were presented following the descriptive method, in tables and charts as well as with the use of graphic means.

\section{Social exclusion}

The notion of social exclusion in its modern sense was probably used for the first time in the publication by R. Lenoir from 1974 entitled Les exclus. It referred to persons residing in France who were not taking part either in social or economic development [Broda-Wysocki 2012, p. 25].

Social exclusion may result from poverty, unemployment, different skin color, religion, disability and others [Jarosz (ed.) 2008].

M. Weber introduced a similar notion of social closing [Weber 2002]. His notion was broadened by F. Parkin by distinguishing the process of isolation of social groups, which leads to the emergence of social inequalities, and as a result to social exclusion [Parkin 2006].

B. Jordan claimed that social exclusion definitely goes beyond the category of extreme poverty, which referred to third world countries, or to post-communist states during transformation. Social exclusion refers to all countries as it results from all types of inequalities, which may be the reasons for different types of discrimination [Jordan 1996].

However, according to the National Strategy of Social Integration for Poland [www2], social exclusion is defined as "the lack or limited possibility to take part in, influence and use basic public institutions and markets, which should be accessible 
to everybody, in particular to the poor", i.e. it is a "situation making it impossible or significantly harder for an individual or a group, according to the law, to fulfill their social roles, use public assets and social infrastructure, collect resources and acquire income in a decent way" [Frąckiewicz (ed.) 2005, p. 11].

In Poland the notion of social exclusion emerged relatively late. In their study on beggars from 1995, S. Marmuszewski and S. Bukowski wrote about their isolation, uprooting, loneliness, alienation, and not about social exclusion [Marmuszewski, Bukowski (ed.) 1995].

Z. Bauman used the notions of the unnecessary, unwanted, rejected, marginalized with reference to those who are today simply called the excluded [Bauman 1998].

Generally speaking, the notion of social exclusion consists of three important dimensions:

1. "Exclusion from the labor market and losing social ties - family and friendly ones or those with social institutions.

2. Losing the opportunity to take part e.g. in consumption due to insufficient financial means or the necessity to live in the slums, the impossibility to implement their own rights, to use educational services or other cultural goods.

3. Some state of social exclusion from the statistical perspective - on the one hand, exclusion consists in a series of progressing changes or limitations in the possibility to take part in economic, political, cultural or social life, and on the other this process is irreversible" [Nowak 2008].

Table 1 presents selected causes and effects of social exclusion.

Table 1. Selected causes and effects of social exclusion

\begin{tabular}{|c|c|}
\hline $\begin{array}{l}\text { Reasons for social } \\
\text { exclusion }\end{array}$ & Results of social exclusion \\
\hline 1 & 2 \\
\hline Poverty & $\begin{array}{l}\text { - consumption limited to goods necessary for survival, } \\
\text { - limited functioning in different areas of life, } \\
\text { individuals and their families being deprived of professional aspirations, } \\
\text { education, healthcare and others, } \\
\text { - impossibility to follow the culture of consumption. }\end{array}$ \\
\hline Unemployment & 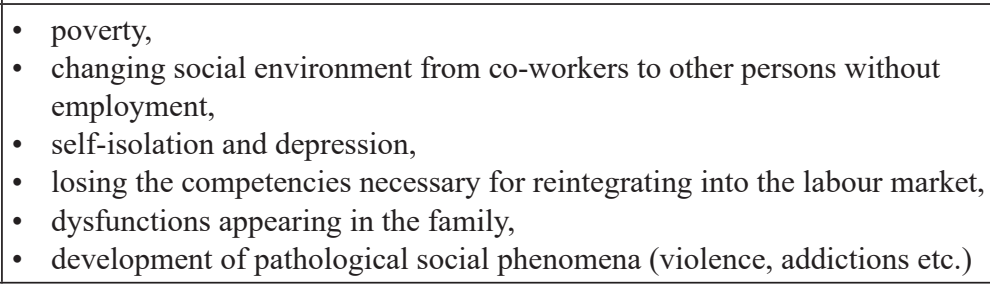 \\
\hline Disability & $\begin{array}{l}\text { - no access or limited access to decision-making within society, } \\
\text { limited opportunity to choose and the bigger necessity to act under duress } \\
\text { in life, } \\
\text { - fewer opportunities and less favorable economic situation, }\end{array}$ \\
\hline
\end{tabular}


Table 1, cont.

\begin{tabular}{|c|c|}
\hline 1 & 2 \\
\hline & $\begin{array}{l}\text { - limited professional opportunities, including education and developing } \\
\text { qualifications, } \\
\text { - limited access to culture, } \\
\text { - remaining in isolation from the rest of the society in medical and care } \\
\text { establishments. }\end{array}$ \\
\hline $\begin{array}{l}\text { Inappropriate living } \\
\text { space }\end{array}$ & $\begin{array}{l}\text { - impeded relaxation and development of family life, } \\
\text { - neglected social and educational infrastructure, } \\
\text { - more difficult to raise children, } \\
\text { low guarantee of protection for the possessed goods and security } \\
\text { of domicile. }\end{array}$ \\
\hline Addictions & $\begin{array}{l}\text { - deteriorating health condition, } \\
\text { - occurrence of depression disorders, } \\
\text { - problems with finding a job or losing a job, } \\
\text { - conflicts with the law. }\end{array}$ \\
\hline Criminal record & $\begin{array}{l}\text { - negative attitude of society towards individuals with a criminal record, } \\
\text { - difficulties in finding a job, } \\
\text { - addictions, } \\
\text { - getting into inappropriate accommodation, } \\
\text { - } \text { poverty. }\end{array}$ \\
\hline $\begin{array}{l}\text { Forming part } \\
\text { of a sexual, national } \\
\text { or ethnic minority, } \\
\text { being a migrant } \\
\text { or refugee }\end{array}$ & $\begin{array}{l}\text { - limited access to goods and benefiting from different assets (economic, } \\
\text { political, social, cultural), } \\
\text { no social trust. }\end{array}$ \\
\hline $\begin{array}{l}\text { Low degree } \\
\text { of education }\end{array}$ & - unemployment. \\
\hline $\begin{array}{l}\text { Unequal access } \\
\text { to education }\end{array}$ & $\begin{array}{l}\text { - limited access to textbooks, additional classes, } \\
\text { - necessity to discontinue education earlier, } \\
\text { - limited access to the labour market. }\end{array}$ \\
\hline Health condition & $\begin{array}{l}\text { - limited access to the labour market, } \\
\text { - poverty, } \\
\text { impeded functioning in different areas of life. }\end{array}$ \\
\hline $\begin{array}{l}\text { No access or skills } \\
\text { necessary to use } \\
\text { modern information } \\
\text { techniques }\end{array}$ & $\begin{array}{l}\text { - limited access to the labour market, } \\
\text { - limited development of professional qualifications, } \\
\text { - problems in accessing public services, } \\
\text { - limited educational opportunities, } \\
\text { limited development and possibility to function within the society. }\end{array}$ \\
\hline
\end{tabular}

Source: [Sobczak 2016, pp. 18-19]. 


\section{Own business activity versus employment contract}

According to Article 3 of the Act on Entrepreneurs Law, business activity is defined as organized economic activity performed on one's own behalf and in a continuous way. The activity is not considered a business activity when the income earned by a natural person from this activity does not exceed in any of the months $50 \%$ of the amount of the minimum remuneration, and who in the period of the last 60 months did not conduct a business activity. According to the Act on Personal Income Tax, Article 5a point 6, business activity is defined as a gainful activity in the field of manufacturing, construction as well as services and the activity consisting in searching for, recognizing and extracting mineral ores from their resources. It should be conducted in a continuous and organized way, on one's own behalf and irrespective of the results. In Article 15 section 2 of the act on the goods and services tax, business activity is defined as all actions undertaken by manufacturers, service providers, traders, farmers as well as entities extracting natural resources. It also includes the activity of freelancers, also when undertaken on a one-off basis, even if the intention was to conduct it on a continuous basis. From such a perspective, in order to define the activity, another important aspect consists in using the goods and intangible assets in a continuous way in order to make a profit.

Business activity is also defined in the general tax regulations act, more specifically in Article 3 point 9. It states that business activity includes the activities defined in this way in the act on the freedom of business activity (Entrepreneurs' Rights), freelance jobs and other gainful activity which is performed on one's own behalf and for their own or someone else's benefit, even if the definitions included in other acts do not consider such activities as conducting a business activity. The act on social insurance system also defines business activity. According to Art. 8, section 6 , the person conducting business activity is: the entity conducting business activity as defined in the act Entrepreneurs' Law, an artist and creator, an entity conducting freelance activity, an entity managing non-public schools or schools based on the act on the educational system, a partner of professional partnership, a limited partnership, a registered partnership or single-person limited liability companies.

The Labour Code defines the notion of an employment contract which constitutes a form of establishing an employment relationship. On the day of concluding the employment contract, an employment relationship is established. The employment contract can be concluded for the trial period, for an indefinite or definite period of time. According to Article 29 of the Labour Code, an employment contract defines the parties to the contract (employer and employee), the type of contract, the date of its conclusion as well as its working and payment conditions, in particular:

1) type of work,

2) place of performing the work,

3) remuneration for the work matching the type of work, specifying the elements of remuneration, 
4) working hours,

5) date of beginning the work.

The employment contract should be drawn up in writing. If the contract was not concluded in writing, before allowing an employee to work, the employer is obliged to confirm with the employee in writing the agreements concerning the parties to the contract, the type of contract and its conditions.

\section{Opinions of socially excluded individuals on conducting business activity and being employed on a full-time basis in view of own research}

\section{Analyzed data ${ }^{1}$}

The analysis included the responses obtained from the questionnaire conducted among the sample of 350 respondents, with 195 of them responding to paper questionnaires and 155 using the questionnaire published online at https:// www.webankieta.pl/ankieta/361581/inkluzja-spoleczna-osob-wykluczonychspolecznie-pracujacych-w-szarej-strefie-motorem-rozwoju-przedsiebiorczosci-wplocku.html.

\section{Statistical analyses plan}

Analyses included the distribution of answers to questions among all respondents forming the sample, together with verifying statistical significance of relations between the answers provided and such variables as: sex, age, education and period of being registered in the Municipal Employment Office. The value of 0.05 was conventionally adopted as the statistical significance threshold. Statistical significance was analyzed based on the values of the likelihood ratio used for analyzing the relationships between categorical variables, i.e. those which divide the respondents into groups when some of the specified categories do not include a lot of respondents.

Statistically significant relationships were complemented with the values of V. Cramer's effect size. The interpretation of the value of this gauge depends on the number of persons surveyed and the number of groups compared. The information about both variables is included in the parameter, called the number of degrees of freedom, provided in brackets next to the values of V. Cramer's parameter. At one degree of freedom, weak effect is expressed by the value of 0.10 , average effect 0.30 and strong effect -0.50 . At two degrees of freedom, weak effect is expressed

\footnotetext{
${ }^{1}$ Scientific studies conducted within the research grant - "Cooperation with Universities" from Płock City Hall.
} 
by the value of 0.07 , average effect -0.21 and strong effect -0.35 . At three degrees of freedom, weak effect is expressed by the value of 0.06 , average effect -0.17 and strong effect -0.29 . At four degrees of freedom, weak effect is expressed by the value of 0.05 , average effect -0.15 and strong effect -0.15 . At five degrees of freedom, weak effect is expressed by the value of 0.04 , average effect -0.12 and strong effect -0.22 . The bigger the value of the number of degrees of freedom, the lower the thresholds of V. Cramer's parameter above which the effect is considered weak, average or strong.

Analyses referring to the results specified on scales from 1 to 6 points were conducted with the use of parameter-free statistical significance tests. Comparisons concerning two groups were conducted based on the Mann-Whitney U test and the comparisons concerning at least three groups were conducted based on Kruskall-Wallis $\mathrm{H}$ test. The Kruskall-Wallis $\mathrm{H}$ test was each time complemented with the Mann-Whitney U test used as the pair comparison test.

Each statistically significant correlation was presented on the graph.

The author first analyzed the opinions of excluded individuals on full-time employment.

Table 2 presents the frequency distribution for the opinion of those surveyed concerning taking up a full-time job at their employer's.

Table 2. Opinions of respondents concerning taking up a full-time job at their employer's

\begin{tabular}{|l|c|c|}
\hline Taking up a job at their employer's & $\mathrm{n}$ & $\%$ \\
\hline Yes & 254 & 72.6 \\
\hline No & 18 & 5.1 \\
\hline Own business activity & 40 & 11.4 \\
\hline Do not know & 24 & 6.9 \\
\hline No data & 14 & 4.0 \\
\hline Total & 350 & 100 \\
\hline
\end{tabular}

Key: $\mathrm{n}$ - number of persons, $\%$ - percentage of the group

Source: own study.

The majority of those surveyed wanted to have a full-time job at their employer's. Statistically significant correlations were obtained between the opinion of respondents and their sex, $\lambda(3)=11.21, p<0.01, V=0.19$ and education, $\lambda(6)=$ 25.76, $p<0.001, V=0.21$.

There were more women who wanted to have a full-time job at their employer's and more respondents with a university or secondary education (cf. Figure 1). 


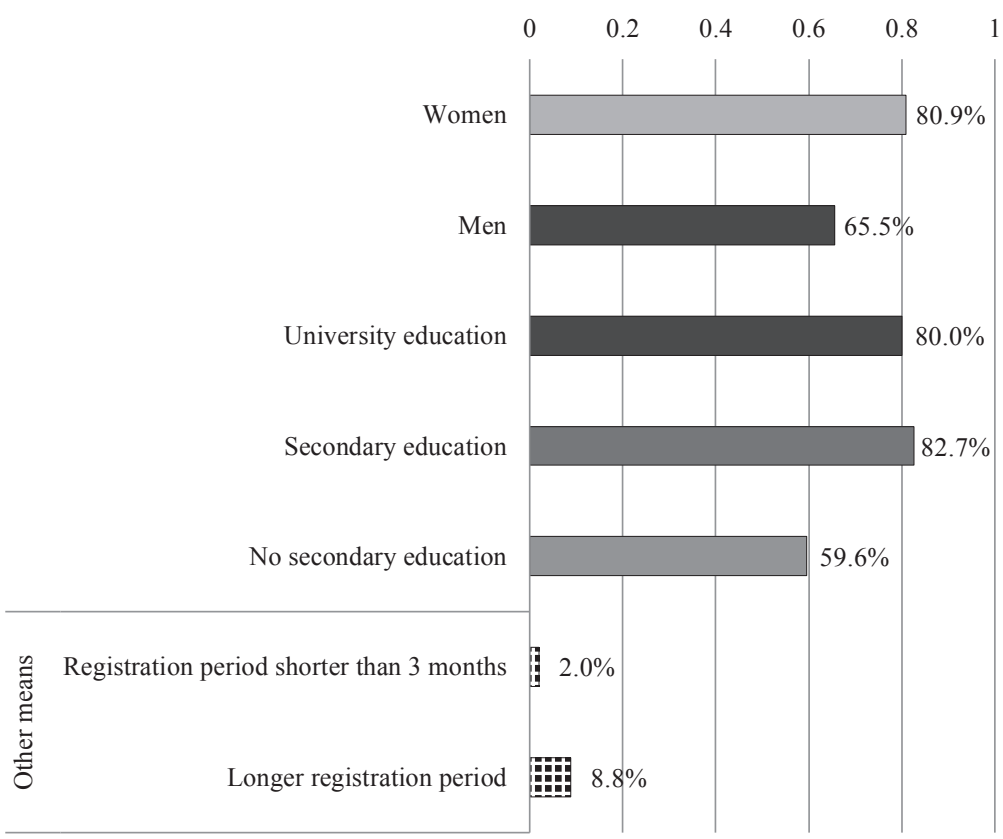

Fig. 1. Statistically significant correlations between the willingness to take up a full-time job at their employer's and the sex and education of respondents

Source: own study.

Table 3 presents descriptive statistics for the assessment of types of business activity that the respondents would like to conduct.

Table 3. Assessment of the assessments of the types of business activity that the respondents would like to conduct

\begin{tabular}{|l|c|c|c|c|}
\hline \multicolumn{1}{|c|}{ Business activity } & $M$ & $S D$ & $\min$ & $\max$ \\
\hline \multicolumn{1}{|c|}{1} & 2 & 3 & 4 & 5 \\
\hline Managing a water park & 1.80 & 1.43 & 1 & 6 \\
\hline Tailoring services & 1.75 & 1.29 & 1 & 6 \\
\hline Renovations and construction repairs & 2.33 & 1.72 & 1 & 6 \\
\hline Trade & $\mathbf{3 . 3 4}$ & $\mathbf{1 . 9 9}$ & $\mathbf{1}$ & $\mathbf{6}$ \\
\hline Transport services & 2.02 & 1.51 & 1 & 6 \\
\hline Childcare or care of the elderly & 2.34 & 1.73 & 1 & 6 \\
\hline Cleaning services & 2.21 & 1.58 & 1 & 6 \\
\hline Hairdressing and beauty services & 2.50 & 1.75 & 1 & 6 \\
\hline Gardening services & 1.88 & 1.38 & 1 & 6 \\
\hline
\end{tabular}




\begin{tabular}{|l|c|c|c|c|}
\hline \multicolumn{1}{|c|}{1} & 2 & 3 & 4 & 5 \\
\hline Counseling services & 2.41 & 1.66 & 1 & 6 \\
\hline Equipment repairs & 2.12 & 1.50 & 1 & 6 \\
\hline Touristic services & 2.20 & 1.60 & 1 & 6 \\
\hline Construction services & 2.63 & 1.76 & 1 & 6 \\
\hline Taxi services & 2.19 & 1.73 & 1 & 6 \\
\hline Other & 2.51 & 1.93 & 1 & 6 \\
\hline
\end{tabular}

Key: $M$ - medium value, $S D$ - standard deviation, $\min$ - minimum value, $\max$ - maximum value Source: own study.

The highest value of assessment was obtained for trade (medium value 3.34, standard deviation 1.99 , minimum value 1 , maximum value 6).

Then, statistical significance was analyzed for the differences between the sexes in the context of the assessments obtained (cf. Figure 2).

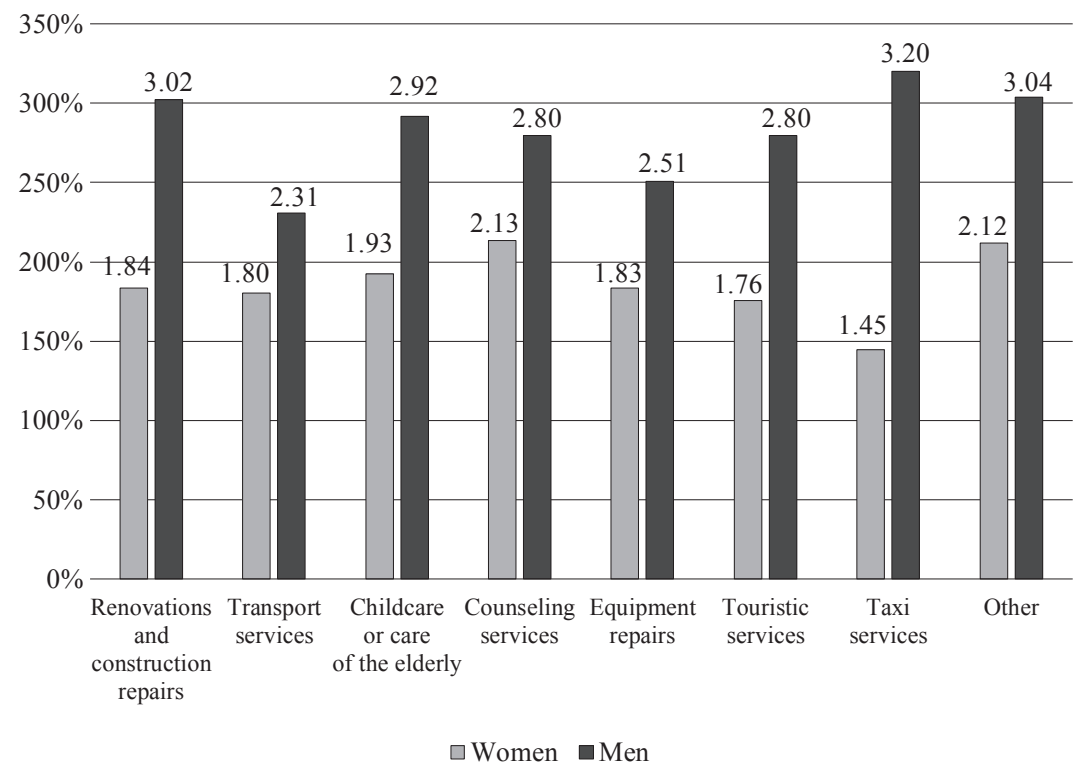

Fig. 2. Assessments of the types of business activity conducted according to the sex of those surveyed Source: own study.

Statistically significant differences were recorded between the groups in the context of the assessment of cleaning services, hairdressing and beauty care services as well as taxi services. Statistically significant differences in the context of the assessment of cleaning services were observed between the respondents with and 
without a secondary education, $U=579.50, p<0.05$. The average value of the assessment was higher in the group of respondents without a secondary education (cf. Figure 3). Statistically significant differences within the assessment of hairdressing and beauty care services were recorded between persons with a university education and respondents with a secondary education $U=443.50, p<0.05$, and those without a secondary education, $U=448.50, p<0.01$. The average value of the assessments obtained in the group of persons with a secondary education was lower than in the remaining two groups. Statistically significant differences in the assessment of taxi services were observed between persons without a secondary education and those with a university education, $U=560.00, p<0.05$ and persons with a secondary education, $U=645.00, p<0.05$. The average value of assessments obtained in the group of respondents without a secondary education was higher than the average values obtained in the two remaining groups.

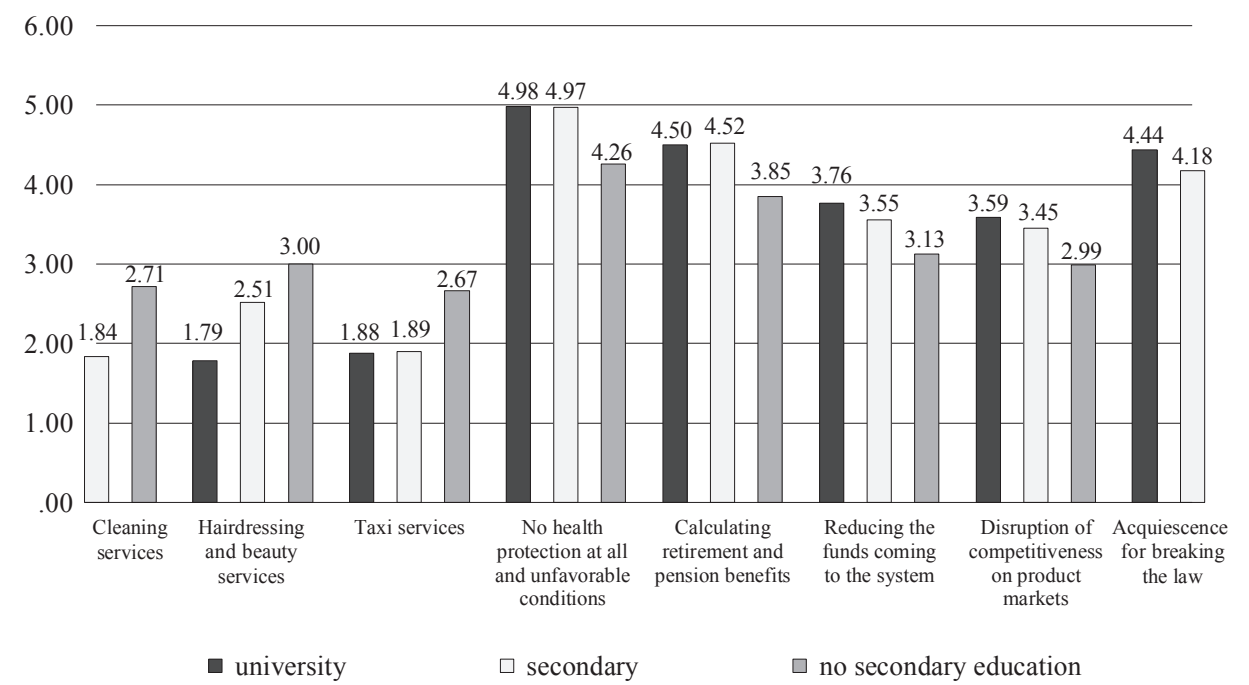

Fig. 3. Statistically significant intergroup differences in the scope of assessing types of economic activity depending on the education of the respondents

Source: own study.

Statistically significant differences were obtained for the assessment of childcare and caring for the elderly and for the assessment of construction services.

\section{Conclusion}

In summarizing the considerations in the article, the author concludes that the phenomenon of social exclusion is common. Socially excluded individuals are, among others, the unemployed. Some of them want to return to the market of registered 
work and take up a job based on an employment contract or begin their own business activity. The conducted research shows that about $73 \%$ of respondents would like to take up a job based on an employment contract. These are most frequently women who declare the need for such work, probably because they feel the need for stability, $81 \%$ of responses. What is more, the respondents with a secondary education most frequently declare their willingness to take up a full-time job ( $83 \%$ of responses). Those surveyed usually show trade as the economic activity that they would like to undertake after entering the labour market.

Statistically significant differences were recorded when it comes to hairdressing and beauty care services, emerging between persons with a university education and those with or without a secondary education. Statistically significant differences were also shown in the context of assessing taxi services, taking place between the respondents without a secondary education and those with a university and secondary education. Moreover, statistically significant differences were recorded for the assessment of childcare and caring for the elderly and for the assessment of construction services.

\section{Bibliography}

Act of 29 August 1997 on General Tax Regulation, Journal of Laws no 137, item 926 as amended. Act of 26 July 1991 on Natural Person Income Tax, Journal of Laws no 80, item 350 as amended. Act of 26 June 1974 Labor Code, Journal of Laws no 24, item 141 as amended.

Act of 11 March 2004 on the Goods and Services Tax, Journal of Laws no 54, item 535 as amended. Act of 6 March 2018 Entrepreneurs' Rights, Journal of Laws, item 650.

Act of 13 October 1998 on Social Insurance System, Journal of Laws no 137, item 887 as amended.

Bauman Z., 1998, Zbędni, niechciani, odtrąceni - czyli o biednych w zamożnym świecie, Kultura i Społeczeństwo, no. 2, pp. 3-18.

Broda-Wysocki P., 2012, Wykluczenie i inkluzja społeczna. Paradygmaty i próby definicji, IPiSS, Warszawa.

Frąckiewicz L. (ed.), 2005, Wykluczenie społeczne, Wydawnictwo Akademii Ekonomicznej w Katowicach, Katowice.

Jarosz M. (ed.), 2008, Wykluczeni. Wymiar społeczny, materialny i etniczny, ISP PAN, Warszawa.

Jordan B., 1996, A Theory of Poverty and Social Exclusion, Polity Press, Cambridge.

Marmuszewski S., Bukowski S. (ed.), 1995, Żebracy w Polsce, Wydawnictwo Baran i Suszczyński, Kraków.

Nowak J., 2008, Potencjalne i realne ograniczenia procesu wykluczenia społecznego, [in:] Nowak J. (ed.), Meandry wykluczenia społecznego, WWSP TWP, Warszawa.

Parkin F., 2006, Marxism and class theory: A bourgeois critique, [in:] Levine R.F. (ed.), Social class and stratification. Classic statements and theoretical debates, Rowman \& Littlefield Publishers Inc.

Sobczak M.J., 2016, Wykluczenie społeczne i inkluzja społeczna z wykorzystaniem podmiotów ekonomii społecznej w Polsce na przykładzie województwa łódzkiego, Wydawnictwo Uniwersytetu Łódzkiego, Łódź.

Weber M., 2002, Gospodarka i społeczeństwo. Zarys socjologii rozumiejącej, Wydawnictwo Naukowe PWN, Warszawa. 